\title{
Effects of Roofing Materials on Harvested Rain Water Quality
}

\author{
OJO, OM
}

Department of Civil Engineering, Federal University of Technology, Akure, PMB 704, Ondo State, Nigeria. Email: omojo@futa.edu.ng; Tel: +2348035638438

\begin{abstract}
The effects of roof materials (corrugated iron, aluminum and asbestos) on the quality of harvested rainwater were evaluated in this study. The physical, chemical and bacteriological characteristics of rainwater collected from the different roof materials were analyzed and the results compared with WHO standard for potable water. The results of the physical analysis revealed that the colour, turbidity, total solids and total dissolved solids fell within WHO acceptable standards for potable water. Also, the calcium and magnesium hardness as well as nitrate and sulphate content of the sampled water fell within WHO permissible limits. The results, however, showed that harvested rain water within the study area is slightly acidic with average $\mathrm{pH}$ values of $6.13,6.25$ and 6.15 respectively for the corrugated iron, aluminum and asbestos roof materials respectively. The water samples analyzed had traces of Lead and Iron with average values of $0.605 \mathrm{mg} / \mathrm{L}$ and $0.715 \mathrm{mg} / \mathrm{L}$ of Lead as well as $0.38 \mathrm{mg} / \mathrm{L}$ and $0.52 \mathrm{mg} / \mathrm{L}$ of Iron for the corrugated and asbestos roof materials respectively. These values exceeded the WHO permissible limits of $0.01 \mathrm{mg} / \mathrm{L}$ and $0.3 \mathrm{mg} / \mathrm{L}$ for Lead and Iron respectively. The microbiological indicators assessed showed no detection for E. coli, while the total heterotrophic plate and total coliform counts fell within permissible limits. However, the presence of heavy metals (iron and Lead) in the rainwater samples in concentrations that exceed WHO permissible limits is an indication of high contamination of the water samples, hence, it is recommended that the rainwater samples should be suitably treated before human consumption.
\end{abstract}

\section{DOI: https://dx.doi.org/10.4314/jasem.v23i4.25}

Copyright: Copyright (C) 2019 Ojo. This is an open access article distributed under the Creative Commons Attribution License (CCL), which permits unrestricted use, distribution, and reproduction in any medium, provided the original work is properly cited.

Dates: Received: 21 March 2019; Revised: 19 April 2019; Accepted 23 April 2019

Keywords: roof materials, harvested rainwater, permissible limits, human consumption

About 1.2 billion people globally lack safe drinking water, and 2.6 billion do not have access to adequate sanitation; while $50 \%$ of the populace in developing countries still has no reasonable access to safe and sustained water supplies (UNESCO, 2003; WHO, 2005; Hughes and Koplan, 2005). According to WHO/UNICEF (2012), only around $16 \%$ of the population of Sub-Saharan Africa have access to safe and adequate water supply through improved piped systems. Eletta and Oyeyipo (2008) opined that water is widely referred to as universal solvent and potable water is essential to the survival of man on planet earth. Water is essential for agriculture, for household water uses such as drinking, cooling, sanitation, as well as for industrial, tourism and cultural purposes (Mark et al., 2002). Water plays a very important role in sustaining the earth's ecosystem. This has made man to embrace different ways of getting water to meet his needs. Rainwater harvesting is a technology use to collect, convey, and store rain for later use from relatively clean surfaces such as a roof, land surface or rock catchment. Rainwater harvesting in urban areas is a strategy that may be employed to cope with current water shortages, urban stream degradation and flooding (Fletcher et al., 2008). The water is generally stored in a rainwater storage tanks which could be above ground or below ground. Rainwater harvesting is still the only source of potable water for rural communities where there are no water networks and currently in Nigeria, roof top rainwater harvesting is being practiced for drinking water, domestic uses, as well as livestock and garden irrigation. Rainwater as it falls from the sky is soft, and is among the cleanest of water sources. However, contamination may result from the environment and roof materials which are used for rainwater collection (Polkowska et al., 2001). Rain water is typically collected from roof tops and stored in tanks or cisterns. But because the roof or any collection surface is subject to contamination from nesting and flying birds and air borne dust, no one should assume that this source of water is the most suitable for human consumption (Obasikene et al, 2000).The typical roofing materials that are used in Nigeria today and particularly in Akure are ceramic tiles, metal sheets, galvanized iron, anodized aluminum and asbestos. All these materials are potential sources of dissolved irons, alkalinity and traced metals (Ayenimo et al., 2006). The objectives of the study were to determine the physical, chemical and bacteriological characteristics of rainwater from 
different roofing sheets and to compare the result obtained with WHO standard for potable water. This study is limited to investigation of the effect of roofing materials (aluminium, corrugated iron and asbestos) by analyzing the physical, chemical and biological properties of the water taking the School of Engineering, Federal University of Technology Akure as the catchment area.

\section{MATERIALS AND METHODS}

Description of Study Area: The study was carried out in the Federal University of Technology Akure (FUTA). The sample point is shown in Figure 1. FUTA was founded in 1981. Akure is the capital of Ondo State which was carved out from the old western state. Akure is about $70^{0} 15^{1}$ north of equator and $50^{\circ}$ $51^{1}$ east of meridian. It has an approximately $40 \mathrm{sqr} \mathrm{mi}$ in area and estimated population of about 484,798 as of 2016 National Population Census. It mean annual temperature ranges from $25-30^{\circ}$, and mean annual rainfall ranges from $2500-3500 \mathrm{~mm}$.

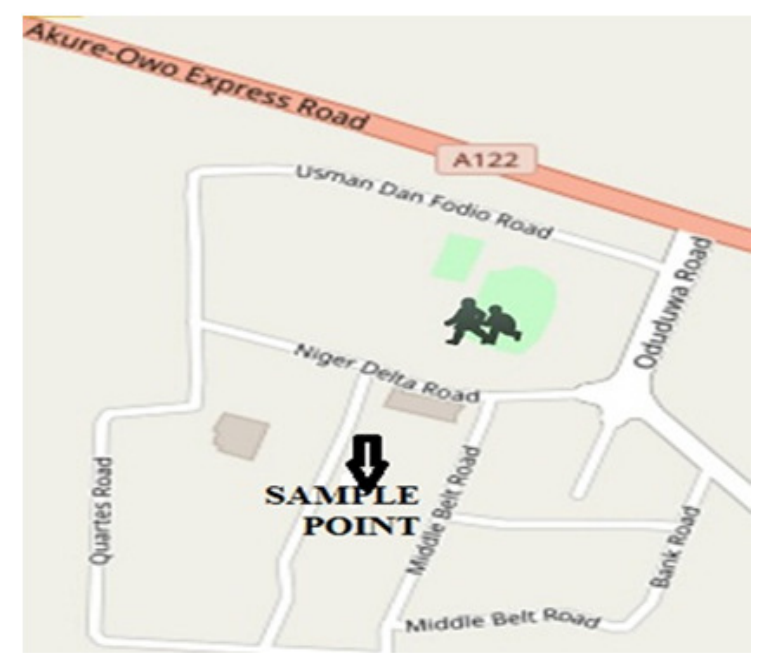

Fig 1: Map of Federal University of Technology Akure showing sample location

Three sets experiment set-up constructed of wooden truss and covered with different types of roofing materials (asbestos, aluminum and corrugated iron sheet) were positioned in an open space, behind the School of Engineering and Engineering Technology Complex, Federal University of Technology Akure.

Sample Collection: Newly sourced five liter plastic kegs fitted with funnels were used to harvest rainwater. The samples were collected in April, 2017. The harvested rainwater samples were properly sealed, labelled and conveyed to the central laboratory of the Federal University of Technology, Akure for physiochemical and bacteriological analysis of the samples.

The rain water samples harvested from various roof materials were labelled sample A, B and C as follows: Sample A: rainwater harvested from corrugated iron roof (pan); Sample B: rainwater harvested from aluminum roof and Sample C: rainwater harvested from asbestos roof.

Laboratory Analysis: The collected samples were taken to the laboratory within two hours of collection and refrigerated at $4{ }^{\circ} \mathrm{C}$ in the laboratory till the analysis was carried out in order to ensure the integrity of the samples. The physical tests carried out on the water samples include colour, turbidity, total solids and total dissolved solids. The chemical tests include $\mathrm{pH}$, calcium and magnesium hardness, nitrate, sulphate, iron, aluminum, copper, zinc, lead and phosphorus. The bacteriological tests include Total Heterotrophic Plate Count, Total Coliforms Count and $e$-coli count. The various physio-chemical and bacteriological analysis were carried out on the water samples according to procedures described in APHA (2005).

Data Analysis: The data obtained from the study were analyzed using IBM SPSS Statistics Version 22.

\section{RESULTS AND DISCUSIONS}

Tables 1, 2 and 3 show the mean value of the physical, chemical and bacteriological characteristics of rainwater harvested from various roof materials respectively. The results of the physical analysis revealed that the colour, turbidity, total solids and total dissolved solids fell within WHO acceptable standards for potable water as shown in Table 1. Table 2 revealed that the calcium and magnesium hardness as well as nitrate and sulphate content of the sampled water fell within WHO permissible limits. However, the $\mathrm{pH}$ values of the harvested rain water samples fell below WHO standard for potable water. The results showed that harvested rain water within the study area is slightly acidic. The acidity of normal rain is attributed to carbonic acid, a natural compound that forms during the water cycle. $\mathrm{pH}$ has no direct effect on human health, but because it is so closely associated with other chemical constituents of water, it is often regarded as having an indirect effect on health and would impact frequently on human health (Ma et al., 2005, WHO, 2011). The phosphorus contents in exceeded the WHO tolerable limit of $0.3 \mathrm{mg} / 1$ for drinking water hence, the water samples are unsafe for drinking in term of its phosphorus content and must be treated to bring the values to $\mathrm{WHO}$ approved limit. 
Table 1: Physical characteristics of harvested rainwater samples

\begin{tabular}{llllll}
\hline S/N & Parameters & $\begin{array}{l}\text { Sample A } \\
\text { Mean } \pm \text { SD }\end{array}$ & $\begin{array}{l}\text { Sample B } \\
\text { Mean } \pm \text { SD }\end{array}$ & $\begin{array}{l}\text { Sample C } \\
\text { Mean } \pm \text { SD }\end{array}$ & $\begin{array}{l}\text { WHO } \\
\text { Standard }\end{array}$ \\
\hline $\mathbf{1}$ & Colour & $5 \pm 0$ & $5 \pm 0$ & $5 \pm 0$ & 5 \\
$\mathbf{2}$ & Turbidity (NTU) & $0.95 \pm 0.1750$ & $0.15 \pm 0.1550$ & $0.85 \pm 0.1500$ & 5 \\
$\mathbf{3}$ & Total Solids & $78.051 \pm 0.7500$ & $52.55 \pm 0.8500$ & $40.685 \pm 0.7750$ & 250 \\
$\mathbf{4}$ & Total Dissolved solids & $18 \pm 0.4000$ & $14.5 \pm 0.6000$ & $22.4 \pm 0.8000$ & 250 \\
\hline
\end{tabular}

Table 2: Chemical characteristics of harvested rainwater samples

\begin{tabular}{llllll}
\hline S/N & Parameters & $\begin{array}{l}\text { Sample A } \\
\text { Mean } \pm \text { SD }\end{array}$ & $\begin{array}{l}\text { Sample B } \\
\text { Mean } \pm \text { SD }\end{array}$ & $\begin{array}{l}\text { Sample C } \\
\text { Mean } \pm \text { SD }\end{array}$ & WHO \\
\hline $\mathbf{1}$ & pH & $6.13 \pm 0.000$ & $6.25 \pm 0.000$ & $6.15 \pm 0.0250$ & $6.5-8.5$ \\
$\mathbf{2}$ & Calcium Hardness (mg/l) & $11.75 \pm 0.110$ & $12.26 \pm 0.110$ & $14.7625 \pm 0.5450$ & $100-300$ \\
$\mathbf{3}$ & Magnesium Hardness (mg/l) & $3.95 \pm 0.150$ & $0.35 \pm 0.150$ & $1.755 \pm 0.6450$ & 250 \\
$\mathbf{4}$ & Nitrate (mg/l) & $1.34 \pm 0.090$ & $6.87 \pm 0.090$ & $25 \pm 9.600$ & $50--$ \\
$\mathbf{5}$ & Sulphate (mg/l) & $12.14 \pm 1.060$ & $10.04 \pm 1.060$ & $11.58 \pm 0.3100$ & 250 \\
$\mathbf{6}$ & Iron (mg/l) & $0.38 \pm 0.040$ & $0.001 \pm 0.040$ & $0.52 \pm 0.050$ & 0.3 \\
$\mathbf{7}$ & Aluminum (mg/l) & $0.025 \pm 0.025$ & $0.015 \pm 0.010$ & $0.045 \pm 0.0150$ & $0.1-0.2$ \\
$\mathbf{8}$ & Copper (mg/l) & $0.74 \pm 0.0500$ & $0.086 \pm 0.050$ & $0.0625 \pm 0.0015$ & 1 \\
$\mathbf{9}$ & Zinc (mg/l) & $0.063 \pm 0.004$ & $0.146 \pm 0.005$ & $0.125 \pm 0.010$ & $3.0-5.0$ \\
$\mathbf{1 0}$ & Lead (mg/l) & $0.605 \pm 0.025$ & $0.005 \pm 0.025$ & $0.715 \pm 0.025$ & 0.01 \\
$\mathbf{1 1}$ & Phosphorus (mg/l) & $7.660 \pm 0.725$ & $6.115 \pm 0.065$ & $4.215 \pm 0.1500$ & 0.3 \\
\hline
\end{tabular}

Table 3: Bacteriological characteristics of harvested rainwater samples

\begin{tabular}{llllll}
\hline S/N & Parameter & $\begin{array}{l}\text { Sample A } \\
\text { Mean } \pm \text { SD }\end{array}$ & $\begin{array}{l}\text { Sample B } \\
\text { Mean } \pm \text { SD }\end{array}$ & $\begin{array}{l}\text { Sample C } \\
\text { Mean } \pm \text { SD }\end{array}$ & WHO \\
\hline $\mathbf{1}$ & Total Heterotrophic Plate Count $(\mathrm{CFU} / \mathrm{ml})$ & $26 \pm 1.0000$ & $21.5 \pm 1.0000$ & $27 \pm 1.0000$ & $0-30$ \\
$\mathbf{2}$ & Total Coliforms Count $(\mathrm{CFU} / 100 \mathrm{ml})$ & $1.15 \pm 0.150$ & $1.26 \pm 0.250$ & $1.25 \pm 0.0250$ & $0-10$ \\
$\mathbf{3}$ & E.Coli Count $(\mathrm{CFU} / \mathrm{ml})$ & - & - & - & 0 \\
\hline
\end{tabular}

The WHO tolerant limit for iron content in drinking water is $0.3 \mathrm{mg} / \mathrm{l}$. It can be seen that the iron content of samples A and C exceeded the WHO acceptable limit for iron content. It implies that the water is unsafe for drinking in term of the level of iron content and must be treated to bring this value within the WHO acceptable limit. Excess intake of iron results in gastrointestinal upset and in severe cases can lead to organ damage.

Traces of Lead found in samples $\mathrm{A}$ and $\mathrm{C}$ exceeded the WHO tolerable limit of $0.001 \mathrm{mg} / \mathrm{L}$ in drinking. This implies that the water is unsafe for drinking in term of it Lead content and must be treatment. Lead is a cumulative poison, especially dangerous for infants and pregnant women. The presence of heavy metals (Iron and Lead) in the rainwater samples in concentrations that exceed WHO permissible limits is an indication of high contamination of the water samples, hence, it is recommended that the rainwater samples should be suitably treated before human consumption (Ojo and Adekunle, 2016). The results also revealed that metal roofs did not always leach higher concentrations of heavy metals as compared to asbestos roofing material. For instance, $\mathrm{Zn}$ and $\mathrm{Fe}$ concentrations in rainwater harvested rainwater were consistently higher from the asbestos roof as compared to the aluminum roof.

The microbiological indicators assessed showed no detection for E. coli $(0 \mathrm{cfu} / \mathrm{ml})$ as shown in Table 3 . The total heterotrophic plate count for samples A, B and $\mathrm{C}$ were found to be within WHO acceptable standards for potable water. Also, the total coliform count for sample A, B and C fell within WHO acceptable limits for drinking water. Therefore the rainwater harvested from the various roofing materials at the School of Engineering, Federal University of Technology, Akure is safe for drinking in respect to it bacteriological content.

Conclusion: This study investigated the quality of rainwater harvested from corrugated iron, aluminum and asbestos roof materials. Results of the laboratory analysis of the harvested rainwater samples collected showed that the rainwater harvested from the roof tops was slightly acidic and contained some contaminants (Iron, Lead and Phosphorus) at levels above WHO drinking water standards. The results obtained from this study indicates that there is a need to treat harvested rainwater prior to potable use.

\section{REFERENCES}

American Public Health Association (APHA) (2005). Standard Methods for the Examination of Water and Wastewater. 20th Edn., American Public Health Association, Washington D.C., U.S.A.

Ayenimo, JG; Adekunle, AS; Makinde, WO; Ogunlusi, GO (2006). Heavy metals fractionation in roof runoff in Ile-Ife, Nigeria. Environ. Sci. Technol. J. 3:221 -227. 
Eletta, OA; Oyeyipo. JO (2008). Rainwater Harvesting: Effects of Age of Roof on water quality. Inter. J. Appl. Chem. 4 (2): $157-162$

Fletcher, TD; Deletic, A; Mitchell, VG; Hatt, BE (2008). Reuse of urban runoff in Australia: a review of recent advances and remaining challenges. J. Environ. Qual. 37: 116-127.

Hughes, JM; Koplan, JP (2005). Saving Lives through Global Safe Water. J. Emerging Infectious Diseases. 11(10): 1636-1637.

Ma, JZ; Wang, XS; Edmunds WM (2005). The characteristics of groundwater resources and their changes under the impacts of human activity in the arid North-West China - a case study of the Shiyang river basin. J. Arid Environ. 61, 277-295

Mark, WR; Xining, C; Sarah, AC (2002). World Water and Food to 2025: Dealing with scarcity. International Food Policy Research Institute, NW, Washington DC, USA

Ojo, OM. (2016). Harvested Rainwater Quality: A Case Study of Aule in Akure, South Western Nigeria. Europ. Sci. J. (11):451-462.

Ojo, OM; Adekunle, TO (2016). Evaluation of Heavy Metals Concentration in Harvested Rain water in
Aule Area of Akure, South Western Nigeria. Inter. J. Sci. Technol., 5 (6): $292-295$.

Polkowska, Z; Grynkiewicz, M; Zabiegala, B; Namiesnik, J (2001). Levels of pollutants in roof runoff water from roads with high traffic intensity in the city of Gdansk, Poland, Pol. J. Environ. Stud. 10-35.

Obasikene, JI; Adinna, EN; Uzoechi, IFA. (2000): Man and the Environment, Computer Edge Publishers, Enugu, pp.115-117.

UNESCO (2003). Water for People, Water for Life: UN world water development report, executive summary. Paris: United Nations Educational, Scientific and Cultural Organization.

WHO (2005). The WHO Report 2005-make every mother and child count. Geneva.

WHO (2011). Guidelines for drinking-water quality. 4th ed. WHO Press Geneva, Switzerland. 541p. Available at: www.who.int/water_sanitation_health/publications.

WHO/UNICEF (2012). Joint Monitoring Programme (JMP) for Water Supply and Sanitation. WHO Press. Printed in the United States of America. 